\title{
PERAN ORGANISASI SOSIAL PREMAN SUPER DALAM PEMBERDAYAAN PEREMPUAN DI MALANG RAYA
}

\author{
1Idham Nourgama Akbar dan ${ }^{2}$ Dwi Sulistiani \\ 1,2UIN Maulana Malik Ibrahim Malang \\ 1idhamgiggsy007@gmail.com \\ 22dwisulistiani@pips.uin-malang.ac.id
}

\begin{abstract}
The research used was descriptive qualitative method which aimed to know the role of the social organization of "Preman Super" in empowering women in City of Malang. In 2012 an initiation from a women's association emerged to form an organization, however, in that year, it was still a matter of planning, and finally a year ahead, in 2013 arose a social organization called "Preman Super" which stood for (Perempuan Mandiri Sumber Perubahan/ The Change of Independent Women) which was found in Malang City. Over time, the organization grew fast until expanded to several regions, like to District of Malang and City of Batu. In addition, the role of the Organization in empowering women had been successfully running since its establishment was to eradicate poverty and empower women through the program they ran. Furthermore, it made women's lives better and more competitive after joining the organization. Therefore, the existence of the organization of "Preman Super" was very significant in social's life, particularly, for women in Malang City.
\end{abstract}

Keywords: Malang, Social Organization, Women Empowerment, Preman Super

\section{Abstrak}

Penelitian ini menggunakan metode kualitatif deskriptif yang bertujuan untuk mengetahui peran organisasi sosial preman super dalam pemberdayaan perempuan di Malang Raya. Di tahun 2010 muncul sebuah inisiasi dari perkumpulan ibu-ibu tersebut untuk membentuk suatu organisasi, tetapi hal tersebut masih menjadi wacana semata dan akhirnya pada tahun 2013 tercetuslah sebuah organisasi sosial yang bernama Preman Super (Perempuan Mandiri Sumber Perubahan) yang didirikan di Kota Malang. Seiring berjalannya waktu Preman Super tidak hanya beroperasi di kota Malang tapi juga di Kabupaten Malang dan Kota Batu. Peran organisasi Preman Super bagi Pemberdayaan Perempuan sebenarnya sudah berjalan dengan baik, karena tujuan berdirinya organisasi Preman Super adalah sebagai pengentas kemiskinan dan pemberdayaan perempuan melalui program yang dijalankannya. Disisi lain organisasi Preman Super telah banyak menjadikan perempuan-perempuan menjadi lebih baik dan memiliki daya saing setelah mereka bergabung dengan organisasi ini. Jadi jelas, peran yang diberikan organisasi Preman Super amatlah penting bagi kehidupan masyarakat khususnya perempuan di Malang Raya.

Kata Kunci: Malang Raya, Organisasi Sosial, Pemberdayaan Perempuan, Preman Super 


\section{PENDAHULUAN}

Proses pembangunan di Indonesia pada kenyataanya tidak sesuai ekspektasi karena beberapa faktor yang mempengaruhi, salah satunya adalah masalah gender dan kemiskinan. Gender adalah konsep yang mengacu pada peran dan tanggung jawab lakilaki dan perempuan yang terjadi akibat dari dan dapat berubah oleh keadaan sosial dan budaya masyarakat yang menyebabkan kemiskinan bagi perempuan (Kepemndagri, 2003). Kemiskinan muncul ketika orang atau sekelompok orang tidak mampu mencukupi tingkat kemakmuran ekonomi yang dianggap sebagai kebutuhan minimal dari standar hidup tertentu (Sadono, 2006). Tetapi makna kemiskinan disini adalah kemiskinan berbasis gender disamping kemiskinan ekonomi. Adapun di Indonesia, istilah gender lazim dipergunakan di Kantor Menteri Negara Peranan Wanita dengan ejaan "jender", diartikan sebagai interpretasi mental dan kultural terhadap perbedaan kelamin, yakni laki-laki dan perempuan. Karena itu, kata "gender" banyak diasosiasikan dengan kata yang lain, seperti ketidakadilan, kesetaraan dan sebagainya.

Agar proses pengembangan minat dan potensi perempuan bisa berjalan dengan lancar menuju era yang maju, maka sudah seharusnya dilakukan pembentukan suatu wadah atau tempat yang efektif guna mengantisipasi semua problem sosial yang ada pada masyarakat, seperti organisasi sosial yang berbasis di kota Malang yakni Preman Super (Perempuan Mandiri Sumber Perubahan) yang sangat bermanfaat bagi kaum perempuan melalui kegiatan yang dijalankan antara lain memberikan pelatihan, pendidikan, pengembangan keterampilan sesuai dengan potensi yang dimiliki masingmasing individu.

Perempuan perlu diberikan kegiatan positif untuk menggali kreativitasnya dan juga pengembangan potensinya, seperti pemberian pelatihan dan juga penyuluhan agar nantinya mereka dapat survive secara skill dan bisa membantu suaminya dalam hal finansial serta memiliki kehidupan yang layak bagi keluarganya. Melihat keadaan seperti itu, maka lembaga sosial Preman Super kota Malang yang berdiri sejak tahun 2013 dengan komitmennya yaitu merubah mindset atau pola pikir perempuan dan mengayomi ibu-ibu rumah tangga yang belum mampu mengembangkan kemampuannya menjadi perempuan yang lebih berguna. Tujuannya yaitu agar perempuan dapat hidup secara mandiri dan mampu secara finansial untuk memenuhi kebutuhan keluarganya tanpa ketergantungan pada orang lain.

Pemberdayaan adalah memanusiakan, dalam arti mendorong orang untuk menampilkan dan merasakan hak asasinya, sedangkan pemberdayaan perempuan adalah suatu kegiatan atau aktivitas yang diberikan kepada perempuan meliputi pelatihan, keterampilan bahkan pendidikan supaya perempuan mampu mengetahui dan dapat menyalurkan skill maupun potensi yang dimilikinya sehingga mampu berkontribusi pada pembangunan di negara Indonesia.

Penelitian yang dilakukan oleh Maulinia (2012), Minarti (2014), Pernikasari (2014) dan Solihah (2016) mengenai pemberdayaan perempuan menunjukkan fakta bahwa masih banyak perempuan di Indonesia ini yang masih membutuhkan pemberdayaan khusunya di bidang kewirausahaan agar bisa membantu ekonomi keluarga. Penelitian tersebut memberikan hasil yang positif bagi perempuan untuk bisa 
memiliki ketrampilan tertentu sehingga bisa membantu ekonomi keluarga mereka, selain itu perempuan menjadi lebih berdaya tidak hanya sebagai ibu rumah tangga.

\section{STUDI PUSTAKA}

Pemberdayaan merupakan terjemahan dari empowerement, yang juga dapat bermakna "pemberian kekuasaan" karena power bukan sekedar "daya", tetapi juga "kekuasaan", sehingga kata "daya" tidak saja bermakna "mampu" tetapi juga "mempunyai kuasa", sedang memberdayakan merupakan terjemahan dari empower. Menurut Merriam Webster dan Oxford English Dictionary, kata empower mengandung dua pengertian, yaitu: (1) to give power atau authority to atau memberi kekuasaan, mengalihkan kekuatan atau mendelegasikan otoritas ke pihak lain; (2) to give ability to atau enable atau usaha untuk memberi kemampuan atau keperdayaan (Guntur, 2009:3). Beberapa ahli mengemukakan definisi pemberdayaan dilihat dari tujuan, proses dan cara-cara pemberdayaan (Suharto, 2009: 59):

a) Pemberdayaan bertujuan untuk meningkatkan kekuasaan orang-orang yang lemah atau tidak beruntung (Ife).

b) Pemberdayaan adalah sebuah proses dengan mana orang menjadi cukup kuat untuk berpartisipasi dalam, berbagi pengontrolan atas, dan mempengaruhi terhadap, kejadian-kejadian serta lembaga-lembaga yang mempengaruhi kehidupannya. Pemberdayaan menekankan bahwa orang memperoleh keterampilan, pengetahuan, dan kekuasaan yang cukup untuk mempengaruhi kehidupannya dan kehidupan orang lain yang menjadi perhatiannya (Parsons).

c) Pemberdayaan menunjuk pada usaha mengalokasikan kembali kekuasaan melalui pengubahan struktur sosial (Swift dan Lewin).

d) Pemberdayaan adalah suatu cara dengan mana rakyat, organisasi, dan komunitas diarahkan agar mampu menguasai (atau berkuasa atas) kehidupannya (Rappaport).

Dalam pengembangannya, istilah pemberdayaan telah menjadi wacana publik dan bahkan seringkali dijadikan kata kunci bagi kemajuan dan keberhasilan pembangunan masyarakat (Alfitri, 2011: 21). Menurut Ife, pemberdayaan memuat dua pengertian kunci, yakni kekuasaan dan kelompok lemah. Kekuasaan diartikan bukan hanya menyangkut kekuasaan politik dalam arti sempit, melainkan kekuasaan atau penguasaan klien atas (Alfitri, 2011: 22):

1) Pilihan personal dan kesempatan hidup: kemampuan dalam membuat keputusan mengenai gaya hidup, tempat tinggal, dan pekerjaan.

2) Pendefinisian kebutuhan: kemampuan menentukan kebutuhan selaras dengan aspirasi dan keinginannya.

3) Lembaga: kemampuan menjangkau, menggunakan dan mempengaruhi pranata masyarakat, seperti lembaga kesejahteraan sosial, pendidikan, dan kesehatan.

4) Ide atau gagasan: kemampuan mengekspresikan dan menyumbangkan gagasan dalam suatu forum atau diskusi secara bebas dan tanpa tekanan.

5) Sumber: kemampuan memobilisasi sumber formal, informal dan masyarakat. 
6) Aktivitas ekonomi: kemampuan memanfaatkan dan mengelola mekanisme produksi, distribusi dan pertukaran barang serta jasa.

7) Reproduksi: kemampuan dalam kaitannya dengan proses kelahiran, berbagai definisi yang diuraikan diatas, maka penulis menyimpulkan bahwa pemberdayaan adalah serangkaian kegiatan yang dilakukan untuk memperkuat kekuasaan dan keberdayaan suatu kelompok yang lemah didalam suatu masyarakat, termasuk kelompok yang mengalami kemiskinan agar mereka memiliki daya dalam memenuhi kebutuhan hidupnya baik secara kelompok maupun sosial. Atau lebih sederhananya, pemberdayaan adalah sebuah proses peningkatan taraf hidup kearah yang lebih baik.

Menurut Payne dalam buku Modern Social Work Theory, tujuan dasar pemberdayaan adalah keadilan sosial dengan memberikan ketentraman kepada masyarakat yang lebih besar serta persamaan politik dan sosial melalui upaya saling membantu dan belajar melalui pengembangan langkah kecil guna tercapainya tujuan yang lebih besar (Alfitri, 2011: 23). Tujuan utama pemberdayaan adalah memperkuat kekuasaan masyarakat, khususnya kelompok lemah yang tidak memiliki ketidakberdayaan, baik karena kondisi internal, (misalnya persepsi mereka sendiri), maupun karena kondisi eksternal (misalnya ditindas oleh struktur sosial yang tidak adil). Secara konseptual, pemberdayaan harus mencakup enam hal berikut:

1. Learning by doing. Artinya, pemberdayaan adalah sebagai proses hal belajar dan ada suatu tindakan konkret yang terus menerus, dampaknya dapat terlihat.

2. Problem solving. Pemberdayaan harus memberikan arti terjadinya pemecahan masalah yang dirasakan krusial dengan cara dan waktu yang tepat.

3. Self evaluation. Pemberdayaan harus mampu mendorong seseorang atau kelompok tersebut untuk melakukan evaluasi secara mandiri.

4. Self development and coordination. Artinya mendorong agar mampu melakukan pengembangan diri dan melakukan hubungan koordinasi dengan pihak lain secara lebih luas.

5. Self selection. Suatu kumpulan yang tumbuh sebagai upaya pemilihan dan penilaian secara mandiri dalam menetapkan langkah kedepan.

6. Self decision. Dalam memilih tindakan yang tepat hendaknya dimiliki kepercayaan diri dalam memutuskan sesuatu secara mandiri (Alfitri, 2011: 24).

Keenam unsur tersebut merupakan pembiasaan untuk berdaya, penguat dan pengait pemberdayaan. Jika keenam unsur pemberdayaan dilakukan secara kontinyu, maka pengaruh yang ditimbulkan semakin lama semakin kuat dan akan melahirkan perubahan yang besar.

Memberdayakan masyarakat memerlukan rangkaian proses yang panjang (tidak seketika), agar mereka menjadi lebih berdaya. Proses pemberdayaan cenderung dikaitkan sebagai unsur pendorong sosial ekonomi dan politik. Proses pemberdayaan masyarakat dapat dilakukan yang dapat disingkat menjadi 5P, yaitu: Pemungkinan, Penguatan, Perlidungan, Penyokongan, dan Pemeliharaan (Alfitri, 2011: 25). 
1) Pemungkinan: menciptakan suasana atau iklim yang memungkinkan potensi masyarakat berkembang secara optimal. Pemberdayaan harus mampu membebaskan masyarakat dari sekat kultural dan struktural yang menghambat.

2) Penguatan: memperkuat pengetahuan dan kemampuan yang dimiliki masyarakat dalam memecahkan masalah dan memenuhi kebutuhannya. Pemberdayaan harus mampu menumbuhkembangkan segenap kemampuan dan kepercayaan diri masyarakat yang menunjang kemandirian mereka.

3) Perlindungan: melindungi masyarakat terutama kelompok lemah agar tidak tertindas oleh kelompok yang kuat, menghindari terjadinya persaingan yang tidak seimbang (apalagi tidak sehat) antara yang kuat dan lemah dan mencegah terjadinya eksploitasi kelompok kuat terhadap kelompok lemah.

4) Penyokongan: memberikan bimbingan dan dukungan agar masyarakat mampu menjalankan peranan dan tugas kehidupannya. Pemberdayaan harus mampu menyokong masyarakat agar tidak jatuh ke dalam keadaan dan posisi yang semakin lemah dan terpinggirkan.

5) Pemeliharaan: memelihara kondisi yang kondusif agar tetap terjadi keseimbangan distribusi kekuasaan antara berbagai kelompok dalam masyarakat. Pemberdayaan harus mampu menjamin keselarasan dan keseimbangan yang memungkinkan setiap orang memperoleh kesempatan berusaha.

Menurut Kiefer, pemberdayaan mencakup 3 dimensi yang meliputi kompetensi kerakyatan, kemampuan sosiopolitik, dan kompetensi partisipatif. Parson et.al. juga mengajukan tiga dimensi pemberdayaan yang merujuk pada:

1. Sebuah proses pembangunan yang bermula dari petumbuhan individual yang kemudian berkembang menjadi sebuah perubahan sosial yang lebih besar.

2. Sebuah keadaan psikologis yang ditandai oleh rasa percaya diri, berguna dan mampu mengendalikan diri dan orang lain.

3. Pembebasan yang dihasilkan dari sebuah gerakan sosial, yang dimulai dari pendidikan dan politisasi orang-orang lemah dan kemudian melibatkan upayaupaya kolektif dari orang-orang lemah tersebut untuk memperoleh kekuasaan dan mengubah struktur-struktur yang masih menekan (Suharto, 2009: 63).

Schuler, Hashemi, dan Riley mengembangkan delapan indikator pemberdayaan, yang mereka sebut sebagai empowerement index atau indeks pemberdayaan, yaitu:

1) Kebebasan mobilitas: kemampuan individu untuk pergi keluar rumah atau wilayah tempat tinggalnya, seperti ke pasar, fasilitas medis, bioskop, rumah ibadah, ke rumah tetangga. Tingkat mobilitas ini dianggap tinggi jika individu mampu pergi sendirian.

2) Kemampuan membeli komoditas kecil: kemampuan individu untuk membeli barang-barang kebutuhan keluarga sehari-hari (beras, minyak tanah, minyak goreng, bumbu); kebutuhan dirinya (minyak rambut, sabun mandi, rokok, bedak, shampo). Individu dianggap mampu melakukan kegiatan ini terutama jika ia dapat membuat keputusan sendiri tanpa meminta izin pasangannya; terlebih jika ia dapat membeli barang-barang tersebut dengan menggunakan uangnya sendiri. 
3) Kemampuan membeli komoditas besar: kemampuan individu untuk membeli barang-barang sekunder atau tersier; seperti lemari pakaian, TV, koran radio, majalah, pakaian keluarga. Seperti halnya indikator diatas, poin tinggi diberikan terhadap individu yang dapat keputusan sendiri tanpa meminta izin pasangannya; terlebih jika ia dapat membeli barang-barang tersebut dengan menggunakan uangnya sendiri.

4) Terlibat dalam pembuatan keputusan-keputusan rumah tangga: mampu membuat keputusan secara mandiri maupun bersama suami/istri mengenai keputusankeputusan keluarga, misalnya mengenai renovasi rumah, pembelian kambing untuk diternak, memperoleh kredit usaha.

5) Kebebasan relatif dari dominasi keluarga: responden ditanya mengenai apakah dalam satu tahun terakhir ada seorang (suami, istri, anak-anak, mertua) yang mengambil uang, tanah, perhiasan dari dia tanpa izinnya, yang melarang mempunyai anak, atau melarang kerja di luar rumah.

6) Kesadaran hukum dan politik: mengetahui nama salah seorang pegawai pemerintah desa/kelurahan; seorang anggita DPRD setempat; nama presiden; mengetahui pentingnya memiliki surat nikah dan hukum-hukum waris.

7) Keterlibatan dalam kampanye dan protes-protes: seseorang dianggap "berdaya" jika ia pernah terlibat dalam kampanye atau bersama orang lain melakukan protes, misalnya, terhadap suami yang memukul istri; istri yang mengabaikan suami dan keluarganya; gaji yang tidak adil; penyalahgunaan bantuan sosial; atau penyalahgunaan kekuasaan polisi dan pegawai pemerintah.

8) Jaminan ekonomi dan kontribusi terhadap keluarga: memiliki rumah, tanah, aset produksi, tabungan. Seseorang dianggap memiliki poin tinggi jika ia memiliki aspek-aspek tersebut secara sendiri atau terpisah dari pasangannya (Suharto, 2009: 65).

Parson et.al menyatakan bahwa proses pemberdayaan umumnya dilakukan secara kolektif. Menurutnya tidak ada literatur yang menyatakan bahwa proses pemberdayaan terjadi dalam relasi satu-lawan-satu antara pekerja sosial dan klien dalam setting pertolongan perseorangan. Meskipun pemberdayaan seperti ini dapat meningkatkan rasa percaya diri dan kemampuan diri klien, hal ini bukanlah strategi utama pemberdayaan (Suharto, 2009: 66).

Dalam konteks pekerjaan sosial, pemberdayaan dapat dilakukan melalui tiga aras atau matra pemberdayaan (empowerement setting): mikro, mezzo, dan makro.

1. Aras Mikro. Pemberdayaan dilakukan terhadap klien secara individu melalui bimbingan, konseling, stress management, crisis intervention. Tujuan utamanya adalah membimbing atau melatih klien dalam menjalankan tugas-tugas kehidupannya. Model ini sering disebut sebagai pendekatan yang berpusat pada Tugas (task centered approach).

2. Aras Mezzo. Pemberdayaan dilakukan terhadap sekelompok klien. Pemberdayaan dilakukan dengan menggunakan kelompok sebagai media intervensi. Pendidikan dan pelatihan, dinamika kelompok, biasanya digunakan sebagai strategi dalam 
meningkatkan kesadaran, pengetahuan, keterampilan, dan sikap-sikap klien agar memiliki kemampuan memecahkan permasalahan yang dihadapinya.

3. Aras Makro. Pendekatan ini disebut juga sebagai Strategi Sistem Besar (large-system strategy), karena sasaran perubahan diarahkan pada sistem lingkungan yang lebih luas. Perumusan kebijakan, perencanaan sosial, kampanye, aksi sosial, lobbying, pengorganisasian masyarakat, manajemen konflik, adalah beberapa strategi dalam pendekatan ini. Strategi Sistem Besar memandang klien sebagai orang yang memiliki kompetensi untuk memahami situasi-situasi mereka sendiri dan untuk memilih serta menentukan strategi yang tepat untuk bertindak (Suharto, 2009: 67).

Dengan merujuk pada tujuan pemberdayaan, proses pemberdayaan dan strategi pemberdayaan yang telah dipaparkan di atas, maka dapat disimpulkan bahwa pada hakikatnya pemberdayaan adalah suatu upaya yang dilakukan untuk meningkatkan daya masyarakat yang mengalami masalah sosial (kemiskinan, ketidakadilan gender, rasis dan diskriminasi). Upaya pemberdayaan ditujukan untuk masyarakat agar mampu hidup lebih tentram dan lebih baik.

Dalam penelitian ini peneliti membahas tentang pemberdayaan perempuan yang sulit untuk mendapatkan haknya, sulit mendapat tempat untuk berkarya terlebih menyalurkan minat dan bakatnya. Hal ini terkait peran dan tanggungjawabnya sebagai seorang perempuan yang kedudukannya tidak setara dengan laki-laki sehingga menimbulkan ketidakadilan gender, sebuah hal yang berdampak pada kesejahteraan perempuan dan mengakibatkan kemiskinan berbasis gender.

Beberapa indikator ketidakadilan yang berbasiskan pada ketimpangan gender dan mengakibatkan kemiskinan perempuan, antara lain adalah:

a) Perempuan seringkali terlibat dalam pekerjaan-pekerjaan pertanian yang tidak dibayar atau dibayar rendah.

b) Perempuan kurang memiliki akses terhadap pendidikan dan pelatihan.

c) Perempuan kekurangan modal untuk membangun usaha sendiri.

d) Perempuan janda yang dengan terpaksa menjadi kepala keluarga tetap tidak dianggap sebagai pencari nafkah utama keluarga, sehingga upahnya jauh lebih rendah dari laki-laki (Noerdin, dkk, 2006: 24-25).

Dengan melihat beberapa faktor diatas, maka pemberdayaan sangat penting untuk dilakukan agar perempuan dapat hidup mandiri dan demi tercapainya kesejahteraan hidup bagi perempuan. Merujuk pada tahapan pemberdayaan yang dijelaskan diatas, maka dalam penelitian ini peneliti ingin mengetahui proses pemberdayaan perempuan di organisasi sosial Preman Super. Dalam kaitannya dengan proses pemberdayaan perempuan adalah dengan cara pemberian pelatihan dan keterampilan pada perempuan agar nantinya, perempuan mampu bersaing dan bisa mandiri secara finansial.

Kemudian untuk strategi pemberdayaan yang dilakukan oleh organisasi sosial Preman Super adalah strategi pemberdayaan "Aras Mezzo" dimana pemberdayaan dilakukan terhadap sekelompok klien sebagai media intervensi juga sebagai strategi dalam meningkatkan kesadaran, pengetahuan, keterampilan, dan sikap-sikap klien agar memiliki kemampuan memecahkan permasalahan yang dihadapinya. Disisi lain, dengan 
pembinaan yang berbasis kelompok, diharapkan bisa memperkuat solidaritas dan rasa kekeluargaan dalam suatu organisasi yang dijalankan.

Kata wanita dianggap berasal dari bahasa Sansekerta, dengan dasar kata wan yang berarti nafsu, sehingga kata wanita mempunyai arti yang dinafsui. Tapi dalam bahasa Inggris wan ditulis dengan kata want, atau men dalam bahasa Belanda, wun dan schen dalam bahasa Jerman. Kata tersebut mempunyai makna like, wish, desire, aim. Kata want dalam bahasa Inggris bentuk lampaunya adalah wanted. Jadi, wanita adalah who is being wanted (seseorang yang dibutuhkan), yaitu orang yang dihasrati atau diingini (KBBI, 1990:448).

Definisi lain menjelaskan bahwa perempuan adalah setengah masyarakat. Masyarakat terdiri dari laki-laki dan perempuan. Laki-laki dilahirkan oleh perempuan. Jika demikian, perempuan adalah masyarakat seutuhnya (Shihab, 2006: 350). Agama Islam memandang posisi perempuan sebagai posisi yang paling penting dalam rumah tangga dan masyarakat sebagai upaya pembentukan generasi Islam. Rasulullah SAW menempatkan posisi ibu yang utama bagi anak-anaknya, sebagaimana sabdanya:

"Abu Hurairah berkata: Datanglah seseorang kepada Nabi SAW. Dan bertanya: siapakah yang berhak aku layani dengan sebaik-baiknya? Jawab Nabi: Ibumu. Kemudian siapa? Jawab Nabi: Ibumu. Kemudian siapa? Jawab Nabi: Ibumu. Lalu siapa lagi? Jawab Nabi: Ayahmu". (Muttafakun 'alaih)

Kalimat Surga terletak dibawah kaki ibu mengandung arti yang dalam. Ungkapan tersebut sudah tidak asing lagi di masyarakat muslim. Artinya, Islam mengangkat martabat serta kemuliaan kaum perempuan (ibu) yang telah dihina pada kehidupan zaman jahiliyah (Shihab, 2006: 351). Dalam suatu hadits juga ditegaskan bahwa Nabi bersabda: "Dari Anas r.a bersabda Rasulullah SAW: Surga itu di bawah telapak kaki ibu". (H.R. Ahmad). Berdasarkan penjelasan tersebut, nampak jelas menunjukkan jika sosok perempuan adalah makhluk terhormat yang wajib dihormati, wajib dimuliakan, wajib dipatuhi dan wajib untuk dilindungi karena kaum perempuan (ibu) merupakan figur dan tiang utama dalam keluarga.

Menurut kamus besar bahasa Indonesia, kodrat diartikan sebagai: (1) kekuasaan Tuhan; manusia tidak akan mampu menentang (atas dirinya) sebagai makhluk Tuhan, (2) hukum alami; benih itu tumbuh menurut kodratnya, (3) sifat yang asli, sifat bawaan; kita harus bersikap dan bertindak sesuai dengan kodrat masingmasing. Jadi, kodrat alam sama artinya dengan hukum alam, demikian juga kodrat Ilahi, artinya kekuasaan Allah (Shihab, 2006: 352). Dari pengertian tersebut, bahwa yang disebut dengan kodrat yaitu hukum alam atau dalam agama Islam disebut dengan hukum Allah atau Sunnatullah.

Selain itu didalam buku yang sama didefinisikan bahwa kodrat adalah suatu kekuatan dan kekuasaan Tuhan. Pengertian kodrat disini lebih mengarah pada sifat biologis dimana perempuan memiliki rahim, payudara, ovarium (indung telur), vagina, memiliki kemampuan untuk haid, hamil, melahirkan, dan menyusui (Subhan, 2004: 11). Dari pengertian kodrat di atas dapat diketahui bahwa yang dimaksud dengan kodrat 
adalah sesuatu yang telah ditetapkan oleh Tuhan dan bersifat kekal atau abadi dan tidak bisa diubah oleh manusia baik bentuk maupun fungsinya.

Pada dasarnya, proses pemberdayaan menjadi kegiatan yang penting karena faktor yang mempengaruhi, antara lain:

a) Adanya marginalisasi terhadap peran perempuan dalam pengambilan keputusan.

b) Rendahnya pendidikan perempuan ketimbang laki-laki.

c) Perempuan masih menerima perlakuan yang diskriminatif di tempat kerja dan sebagainya (Noerdin, 2006: 16-17).

Berdasarkan masalah di atas, tujuan diadakannya program pemberdayaan perempuan adalah memberikan langkah konkret bagi kaum perempuan agar perempuan bisa mandiri dan memiliki hak atas kehidupannya yang layak demi tercapainya kesetaraan hak perempuan dengan laki-laki. Kata mandiri didalam kamus bahasa Indonesia memiliki arti bebas, tidak bergantung. Jadi dapat disimpulkan bahwa mandiri adalah mampu hidup tanpa menggantungkan hidupnya pada orang lain dan dalam arti yang lain perempuan juga harus menyadari bahwa dirinya adalah pribadi yang punya kehendak bebas.

\section{METODE PENELITIAN}

Penelitian ini menggunakan pendekatan kualitatif. Dalam penelitian ini, jenis penelitian yang digunakan adalah studi kasus, dengan pendekatan ini maka peneliti menggali lebih mendalam tentang fokus penelitian di organisasi sosial Preman Super sehingga nantinya dapat diperoleh kesimpulan tentang peran organisasi sosial Preman Super dalam pengembangan sosial ekonomi pemberdayaan perempuan di Malang Raya. Objek penelitian ini beralamat di Jln. Plaosan Timur Gg. Lori No. 5 RT 06 RW 09, Kecamatan Blimbing Kota Malang karena lokasi atau akses yang terjangkau.

Data yang digunakan dalam penelitian ini terdiri dari data primer dan data sekunder. Data primer dilakukan melalui wawancara dengan pembina sekaligus pendiri organisasi Preman Super untuk menggali informasi tentang pengembangan sosial ekonomi dan pemberdayaan perempuan. Data sekunder diperoleh melalui internet, foto, profil organisasi. Data merupakan perwujudan dari informasi dengan sengaja digali untuk dikumpulkan guna mendeskripsikan suatu peristiwa atau kegiatan lainnya, demikian pula halnya untuk menguji hipotesa yang telah dirumuskan (subagyo, 2004). Pengumpulan data pada dasarnya merupakan suatu kegiatan operasional agar tindakannya masuk pada pengertian penelitian yang sebenarnya. Sumber data terdiri dari dua jenis yaitu data yang bersumber dari manusia dan data yang bersumber dari non manusia.

Teknik pengumpulan data yang digunakan adalah wawancara, observasi dan dokumentasi. Wawancara yaitu proses tanya jawab dalam penelitian yang berlangsung secara lisan antara dua orang yakni pewawancara (interviewer) dan terwawancara (interviewee) atau lebih bertatap muka mendengarkan secara langsung informasiinformasi atau keterangan-keterangan (Narbuko, 2007). Jadi, wawancara dapat diartikan sebagai suatu bentuk komunikasi verbal yang merupakan dialog/percakapan 
yang dilakukan oleh pewawancara dan informan yang bertujuan untuk mendapatkan atau menggali suatu informasi dari informan. Dalam penelitian ini wawancara dilakukan untuk mencari dan menggali informasi tentang peran organisasi sosial Preman Super dalam pemberdayaan perempuan di Malang Raya. Penelitian ini dilakukan secara langsung dengan responden dan direkam.

Observasi adalah pengamatan yang dilakukan secara sengaja, sistematis mengenai fenomena sosial dengan gejala-gejala psikis untuk kemudian dilakukan pencatatan (Soemitro, 1985). Observasi juga merupakan proses yang kompleks, yang tersusun dari proses biologis dan psikologis. Dalam menggunakan teknik observasi yang terpenting adalah mengandalkan pengamatan dan ingatan peneliti (Usman, 1996). Observasi dilakukan untuk mendapatkan data tentang bagaimana peran organisasi sosial Preman Super dalam pemberdayaan perempuan. Jadi dari data observasi dapat diketahui bagaimana peran organisasi sosial Preman Super dalam pemberdayaan perempuan di Malang Raya.

Dokumen yang digunakan oleh peneliti untuk memperoleh data adalah berupa laporan kegiatan, laporan anggota, dan juga foto selama kegiatan pelatihan dan juga rapat anggota. Dokumentasi merupakan catatan tertulis yang didapat dari lokasi penelitian (Arikunto, 2015). Dokumen juga merupakan teknik pengumpulan data yang ditujukan kepada subjek penelitian. Dokumen bisa berbentuk catatan pribadi, surat pribadi, buku harian, laporan kerja, catatan kasus, rekaman video, foto dan lain sebagainya (Arikunto, 2015). Sedangkan sumber data tertulis, foto, dan sejenisnya adalah sumber data tambahan. Studi dokumen merupakan pelengkap dari penggunaan metode observasi dan wawancara dalam penelitian kualitatif. Teknik penelitian dilakukan oleh peneliti adalah untuk mencari sumber data tertulis seperti profil organisasi serta data-data yang tersedia dalam organisasi tersebut.

Dalam penelitian ini, teknik analisis yang digunakan peneliti adalah teknik analisa deskriptif kualitatif (berupa kata-kata dan bukan dengan angka). Miles dan Huberman mengemukakan bahwa aktivitas dalam analisis data kualitatif dilakukan secara intensif dan berkelanjutan hingga tuntas mulai dari data reduction, display data, dan conclusion drawing/verification (Arikunto, 2015).

Mereduksi data (data reduction) merupakan proses penyederhanaan, pengabstrakan dan transformasi data mentah dari catatan tertulis dilapangan. Dengan demikian data tersebut dapat disederhanakan dan ditransformasikan kedalam berbagai macam cara melalui ringkasan singkat dan sebagainya. Penyajian data (display data) disajikan dalam bentuk tulisan, bagan, dan sejenisnya. Penyajian data sebagai kesimpulan informasi yang tersusun dan memberi kemungkinan adanya pengambilan kesimpulan. Dengan demikian penyajian data harus apa yang harus dipahami dan dilakukan lebih jauh. Langkah terakhir dalam penelitian kualitatif adalah penarikan kesimpulan. Kesimpulan (conclusion) ditarik dari hasil penafsiran dan evaluasi. Penyajian data yang telah didukung oleh data-data yang mantap maka dapat disimpulkan.

Pelaksanaan penelitian yang dilakukan di organisasi sosial Preman Super Kota Malang dilakukan dengan tahapan sebagai berikut: 
1. Tahap sebelum ke lapangan. Meliputi kegiatan penentuan fokus penelitian, memilih lapangan penelitian, permohonan izin kepada subyek yang akan diteliti, penelitian pendahuluan, dan penyusunan usulan penelitian.

2. Tahap pekerjaan lapangan. Memahami latar penelitian, mengumpulkan bahan yang akan digunakan untuk subyek penelitian yang berkaitan dengan peran organisasi sosial Preman Super, memasuki lapangan, peran serta dan pengumpulan data melalui teknik wawancara, observasi, dan dokumentasi.

3. Tahap analisis data. Kegiatan analisis data yang diperoleh melaui wawancara, observasi, maupun dokumentasi dengan pendiri organisasi sosial Preman Super, kemudian dilakukan penafsiran data hingga pengecekan keabsahan data dengan cara mengecek sumber data yang diperoleh sehingga data benar-benar valid dan akurat sebagai syarat pemberian makna data yang merupakan proses dalam penelitian yang sedang diteliti.

\section{HASIL PENELITIAN}

Berdirinya organisasi sosial Preman Super di Kota Malang merupakan sebuah ide yang brilian, hal tersebut didasari karena fokus utamanya adalah memberdayakan perempuan. Di tahun 2010 muncul sebuah inisiasi dari perkumpulan ibu-ibu tersebut untuk membentuk suatu organisasi, tetapi hal tersebut masih menjadi wacana semata dan akhirnya pada tahun 2013 tercetuslah sebuah organisasi sosial yang bernama Preman Super (Perempuan Mandiri Sumber Perubahan) yang didirikan di Kota Malang.

Ide terbentuknya organisasi Preman Super berawal dari sebuah perkumpulan ibu-ibu rumah tangga dengan tujuan awal untuk bertukar ilmu dan bertukar keterampilan. Tetapi, seiring berjalannya waktu semakin banyak orang yang tertarik untuk berkumpul dan mereka menemukan dampak serta manfaat dari perkumpulan itu. Perempuan yang awalnya hanya ibu rumah tangga biasa, melalui perkumpulan itu akhirnya mereka bisa mengetahui potensi yang dimilikinya dan memiliki kesempatan untuk mengembangkan potensinya.

Organisasi Sosial Preman Super merupakan sebuah organisasi yang memiliki peran penting bagi perempuan untuk menyalurkan bakat dan minat serta mengasah potensi yang dimilikinya agar kelak bisa menciptakan sesuatu yang bernilai jual serta diharapkannya dari suatu organisasi sosial tersebut mampu menghasilkan perempuanperempuan yang tangguh, memiliki skill, dan mandiri secara finansial serta menjadi sumber perubahan bagi masing-masing keluarganya, memiliki kecakapan didepan publik, tidak minder dan memiliki rasa percaya diri sesuai dengan harapan dari Ibu Peni Budi Astuti selaku pendiri dan pembina organisasi sosial Preman Super Kota Malang.

Organisasi Preman Super saat ini telah memiliki anggota yang jumlahnya \pm 200 anggota yang didominasi oleh perempuan. Kemudian yang masih aktif sebagai anggota berjumlah \pm 120 orang, juga ada anggota yang berjenis kelamin laki-laki. Tetapi secara strukutur kepengurusan organisasi, yang memiliki hak adalah perempuan dikarenakan backgroundnya adalah organisasi yang berbasis pemberdayaan perempuan. Dalam 
tubuh organisasi Preman Super terdapat beberapa pelatihan yang diberikan kepada anggotanya, diantaranya adalah pelatihan tentang memasak, handicraft (kerajinan tangan) dan kesenian. Di sisi lain dampak yang terlihat dari adanya Preman Super adalah adanya perubahan secara signifikan pada hal kreativitas dan berkembangnya skill, para anggota Preman Super juga lebih kompeten di masing-masing bidang yang mereka tekuni karena didalam organisasi ini para anggota diberikan pendidikan dan diikut sertakan dalam pelatihan-pelatihan yang biasa diadakan dengan dinas terkait.

Keberadaan organisasi Preman Super, diharapkan dapat membuat wanita sadar bahwa mereka memiliki potensi dan kemampuan untuk dikembangkan dan juga diasah demi terciptanya perempuan-perempuan tangguh, percaya diri, dan mampu berdaya saing yang unggul. Organisasi preman super dibentuk untuk mencapai visi organisasi yaitu "Menjadi Komunitas UMKM yang berpengaruh dalam menumbuhkan dan membesarkan anggota UMKM Preman Super khususnya dan UMKM secara luas yang berkualitas." Inspirasi preman super adalah mencerahkan, mengajarkan dan memberdayakan sehingga diharapkan dalam hal memberdayakan, preman super dapat memberikan kesempatan dan dukungan untuk mendorong para perempuan agar menjadi percaya diri dalam mengembangkan bakat dan keterampilannya. Preman Super berazaskan kepada keutuhan Hak Azasi Manusia universal dengan lebih mengedepankan semangat gotong royong, kekeluargaan, kebersamaan dan musyawarah mufakat dalam pelaksanaannya. Preman Super berlandaskan Pancasila dan Undang-Undang Dasar 1945. Preman Super bersifat Independen, terbuka dan demokratis, tidak terlibat dalam kepentingan dan kegiatan politik praktis, terorisme dan hal-hal yang berbau SARA.

Keberadaan suatu instansi atau suatu organisasi tidak lepas dari adanya suatu struktur yang terdapat didalamnya. Dalam pembentukan organisasi Preman Super diperlukan adanya struktur organisasi sebagai penempatan posisi atau pengkoordinasian agar dapat mengatur ketertiban dan kelancaran kegiatan yang diterapkan dalam organisasi Preman Super. Begitu juga dengan organisasi Preman Super yang dalam menjalankan tugas-tugas organisasi diperlukan adanya struktur yang memudahkan pengorganisasian. Adapun struktur organisasi Preman Super dibagi dalam kantor pusat dan kantor wilayah kota malang, kabupaten malang dan kota bat. Setiap kantor terdiri dan ketua, sekretaris dan bendahara, dimana di pusat terdapar pimpinan dan pembian organisasi preman super, sedangkan di kantor wilayah terdapat 5 divis-divisi dan 10 bidang sesuai dengan kebutuhan masing-masing.

Pemberdayaan adalah suatu cara dimana rakyat, organisasi, dan komunitas diarahkan agar mampu menguasai (atau berkuasa atas) kehidupannya. Pemberdayaan juga bertujuan untuk meningkatkan kekuasaan orang-orang yang lemah atau tidak beruntung. Disamping itu, pemberdayaan menekankan bahwa orang memperoleh keterampilan, pengetahuan, dan kekuasaan yang cukup untuk mempengaruhi kehidupannya dan kehidupan orang lain yang menjadi perhatiannya. Pada dasarnya proses pemberdayaan menjadi kegiatan yang penting karena faktor yang mempengaruhi, salah satunya adalah rendahnya pendidikan perempuan ketimbang laki-laki, pembagian peran berdasarkan gender yang mengakibatkan perempuan 
diasosiasikan dengan kegiatan yang berada di lingkup domestik dan laki-laki dengan lingkup publik. Hal ini memperkecil akses perempuan terhadap kerja-kerja yang biasanya diasosiasikan dengan ranah publik dan berada di sektor formal.

Berdasarkan beberapa masalah diatas, tujuan diadakannya program pemberdayaan perempuan adalah memberikan langkah konkret bagi kaum perempuan agar perempuan bisa mandiri dan memiliki hak atas kehidupannya yang layak demi tercapainya kesetaraan hak perempuan dengan laki-laki tanpa ada perbedaan gender. Dalam hal ini organisasi sosial Preman Super dinilai memiliki jawaban atas problem yang masih menjadi masalah klasik bagi kaum perempuan pada umumnya karena telah menjalankan tugasnya sebagai salah satu pelopor kegiatan pemberdayaan perempuan di Malang Raya melalui kegiatan-kegiatan yang dilaksanakan.

Organisasi Preman Super dapat memberikan solusi yang tepat bagi perempuanperempuan Indonesia khususnya Malang Raya karena fokus utamanya adalah pemberdayaan perempuan dan aktivitasnya diatur sesuai dengan visi misinya yakni meningkatkan kapasitas anggota guna mendukung gerakan ekonomi kreatif, memberikan pencerahan untuk membuka wawasan dan pikiran kepada para perempuan supaya percaya diri, berfikir maju, dan mampu mengarah kreativitas mereka, memberikan kesempatan dan dukungan untuk mendorong para perempuan agar menjadi percaya diri dalam mengembangkan bakat dan keterampilannya. Tujuannya agar mereka lebih mandiri dan bisa turut berperan memberikan sumbangsih terhadap masyarakat.

Kegiatan pemberdayaan yang dilakukan dalam organisasi Preman Super pun beragam, antara lain dengan metode pelatihan program, pembentukan karakter dan juga kegiatan-kegiatan yang menumbuhkan jiwa kepemimpinan bagi perempuan agar nantinya mereka bisa menjadi perempuan yang mandiri dan memiliki kreativitas yang berguna bagi kehidupannya. Dalam organisasi Preman Super juga terdapat banyak program yang disediakan dan disesuaikan dengan potensi yang dimiliki setiap individu. Sebagai contoh, anggota A memiliki keahlian menyulam, dan anggota B memiliki keterampilan memasak, jadi mereka akan diberikan pengertian dan dilatih untuk meningkatkan skill mereka secara intensif. Nanti jika kemampuan mereka dinilai sudah berkembang, mereka akan diikutkan kedalam sebuah pelatihan yang dilaksanakan oleh instansi terkait yang sudah menjadi partner dari Preman Super sesuai dengan bidang yang ditekuni masing-masing anggota. Setelah mengikuti pelatihan, para delegasi akan menjadi pemateri untuk memberikan materi pelatihan yang didapat kepada anggota yang masih baru.

Hal tersebut dipertegas oleh pernyataan Ibu Tri Ida Mulyani selaku anggota Preman Super dalam wawancara singkatnya mengatakan: "bener mas, waktu itu saya diikutkan pelatihan memasak oleh Preman Super ke dinas yang sudah bekerja sama dengan Preman Super, disana saya dan anggota lain bisa belajar dan meningkatkan kemampuan saya dalam hal memasak, sepulang dari pelatihan dari dinas, saya ditunjuk jadi pemateri dan membagikan pengalaman kepada anggota lain yang masih pemula".

Selain itu, Preman Super juga memiliki program lain yang bernama Sosio-Bisnis atau berkumpul dan berbisnis. Jadi program ini memberikan peluang bagi para anggota 
untuk berkreasi dan memproduksi sebuah barang yang nantinya akan dipamerkan kesebuah event dan acara-acara kesenian, dalam event tersebut para anggota bisa memperkenalkan produknya kepada para pelaku usaha/pelaku bisnis sekaligus melatih keberanian berbicara didepan publik. Jadi disamping berkumpul antar anggota, mereka juga melakukan kegiatan bisnis dengan pelaku usaha.

Menurut hasil wawancara peneliti dengan Ibu Ida Apriliandawati selaku ketua Preman Super mengenai pemberdayaan perempuan: "jadi tujuan pemberdayaan itu sendiri adalah proses menyadarkan, mengajarkan dan memberikan wawasan agar perempuan itu memiliki kesadaran bahwa mereka itu mampu untuk menjadi mandiri dan tidak menggantungkan nasib pada orang lain".

Berdasarkan hasil wawancara diatas dapat dijelaskan bahwa pemberdayaan perempuan didalam organisasi Preman Super adalah untuk memberikan peluang, memberikan pengetahuan dan juga dorongan agar perempuan menjadi sosok yang berguna bagi keluarga maupun masyarakat. Terlebih, keberadaan Preman Super ditengah masyarakat juga harus diapesiasi karena telah membawa perubahan yang sangat signifikan dan dampak yang ditimbulkan juga sangat bermanfaat bagi seluruh lapisan masyarakat, mulai dari warga, sampai pemerintah Malang Raya. Hal tersebut dikatakan oleh Ibu Peni selaku pembina Preman Super mengenai dampak keberadaan Preman Super sebelum maupun sesudah berdiri, beliau mengatakan: "sebelum munculnya organisasi Preman Super bisa dikatakan kondisi masyarakat itu memprihatinkan mas, masih banyak perempuan-perempuan ataupun ibu-ibu yang masih menjadi pemulung dan tidak memiliki pendapatan yang pasti, mereka masih takut untuk bergaul dengan sesama karena merasa mider dan tidak yakin dengan kemampuannya, akhirnya saya memberikan pengertian pada mereka bahwa mereka bisa, ya awalnya memang sulit ya tapi perubahan kan harus dilakukan dan alhamdulillah sampai sekarang anggota yang bergabung sudah lebih dari 125 anggota dan sebagian dari mereka juga sudah memiliki pendapatan yang tetap dengan menjual produk yang diciptakannya".

Pernyataan diatas memberikan bukti bahwa Preman Super telah menjalankan tugasnya yakni sebagai organisasi yang bertujuan untuk menjadikan perempuan lebih berdaya dan berguna demi kesejahteraan hidupnya, selain itu semua kegiatan yang dilakukan organisasi ini bukan untuk mencari keuntungan, tetapi semua dilakukan sebagai bentuk pengabdian kepada masyarakat dan membina masyarakat khususnya perempuan agar menjadi sosok perempuan yang tangguh, kreatif, menjadi sumber perubahan, dan mandiri secara finansial.

\section{PEMBAHASAN}

Dalam penjelasan sebelumnya telah dipaparkan data mengenai peran pendidikan non formal bagi pengembangan sosial dan ekonomi dalam organisasi sosial Preman Super, yang telah berjalan sesuai dengan ekspektasi. Selanjutnya adalah tentang pembahasan peran pendidikan non formal bagi pemberdayaan perempuan dalam organisasi sosial Preman Super. Seperti yang telah dibahas di bab 2 mengenai 
pemberdayaan bahwa pemberdayaan bisa dikatakan sebagai sebuah proses peningkatan taraf hidup kearah yang lebih baik.

Tujuan utama pemberdayaan adalah memperkuat kekuasaan masyarakat, khususnya kelompok lemah yang tidak memiliki ketidakberdayaan, baik karena kondisi internal, (misalnya persepsi mereka sendiri), maupun karena kondisi eksternal (misalnya ditindas oleh struktur sosial yang tidak adil). Secara konseptual pemberdayaan menurut Alfitri (2011) memiliki enam pokok diantaranya:

1. Learning by doing. Artinya, pemberdayaan adalah sebagai proses hal belajar dan ada suatu tindakan konkret yang terus menerus, dampaknya dapat terlihat.

2. Problem solving. Pemberdayaan harus memberikan arti terjadinya pemecahan masalah yang dirasakan krusial dengan cara dan waktu yang tepat.

3. Self evaluation. Pemberdayaan harus mampu mendorong seseorang atau kelompok tersebut untuk melakukan evaluasi secara mandiri.

4. Self development and coordination. Artinya mendorong agar mampu melakukan pengembangan diri dan melakukan hubungan koordinasi dengan pihak lain secara lebih luas.

5. Self selection. Suatu kumpulan yang tumbuh sebagai upaya pemilihan dan penilaian secara mandiri dalam menetapkan langkah kedepan.

6. Self decision. Dalam memilih tindakan yang tepat hendaknya dimiliki kepercayaan diri dalam memutuskan sesuatu secara mandiri.

Berdasarkan ke enam unsur tersebut, organisasi Preman Super telah memiliki semua unsur tersebut. Mulai dari makna learning by doing, problem solving, self evaluation, self development and coordination, self selection, self decision itu telah diterapkan didalam organisasi Preman Super karena keenam unsur tersebut telah menjadi visi dan misi dari organisasi Preman Super.

Pada prosesnya organisasi Preman Super telah memberikan sebuah jawaban atas masalah yang dihadapi oleh perempuan khususnya di Kota Malang. Dalam tubuh organisasi ini telah diterapkan sebuah tradisi yang menjunjung tinggi rasa persaudaraan yang tinggi demi terciptanya kesejahteraan diantara para anggota. Hal tersebut didasarkan pada tiga inspirasi yaitu:

Enlighten (Mencerahkan): Memberikan pencerahan untuk membuka wawasan dan pikiran kepada para perempuan supaya percaya diri, berfikir maju, dan mampu mengarah kreativitas mereka tanpa mengabaikan peran dan fungsinya sebagai ibu dan istri dalam keluarga.

Educate (Mengajarkan): Mendorong terciptanya kondisi yang merangsang terjadinya proses saling berbagi dan saling melakukan pembelajaran, agar para perempuan lebih percaya diri dalam mendidik dan menciptakan lingkungan yang baik dan sehat bagi anak-anak serta keluarganya.

Empower (Memberdayakan): Memberikan kesempatan dan dukungan untuk mendorong para perempuan agar menjadi percaya diri dalam mengembangkan bakat dan keterampilannya. Tujuannya agar mereka lebih mandiri dan bisa turut berperan memberikan sumbangsih memberdayakan keluarga maupun masyarakat sekitarnya. 
Merujuk pengertian diatas dapat dikatakan bahwa Preman Super memiliki rasa empati dan juga kepedulian yang tinggi terhadap para perempuan agar kaum perempuan memiliki kesadaran dan memiliki keyakinan bahwa mereka bisa menjadi perempuan mandiri sumber perubahan bagi keluarganya.

\section{PENUTUP}

Peran organisasi Preman Super bagi Pemberdayaan Perempuan sebenarnya sudah berjalan dengan baik, karena tujuan berdirinya organisasi Preman Super adalah sebagai pengentas kemiskinan dan pemberdayaan perempuan melalui program yang dijalankannya. Dan disisi lain organisasi Preman Super telah banyak menjadikan perempuan-perempuan menjadi lebih baik dan memiliki daya saing setelah mereka bergabung dengan organisasi ini. Jadi jelas, peran yang diberikan organisasi Preman Super amatlah penting bagi kehidupan masyarakat khususnya perempuan di Malang Raya.

Adapun saran dari penulis tentang peran organisasi Preman Super bagi pengembangan Sosial Ekonomi dan Pemberdayaan Perempuan, diantaranya:

1. Organisasi Preman Super harus memiliki perhatian dan membuka pintu bagi daerahdaerah lain yang sama-sama memerlukan bantuan dalam rangka pengembangan ekonomi dan pemberdayaan perempuan.

2. Untuk seluruh elemen masyarakat hendaknya memberikan apresiasi dan motivasi atas sumbangsih yang telah diberikan organisasi Preman Super atas perannya dalam pengentasan kemiskinan dan pemberdayaan masyarakat khususnya perempuan.

3. Kepada pemerintah Kota Malang, Kabupaten Malang dan Kota Batu hendaknya memberikan fasilitas pada organisasi Preman Super agar bisa membuka cabang di wilayah lain sehingga proses pengentasan kemiskinan dapat berkurang.

\section{DAFTAR PUSTAKA}

Adi, Isbandi Rukminto. (2003). Pemberdayaan, Pengembangan Masyarakat dan Intervensi Komunitas (Pengantar Pada Pemikiran dan Pendekatan Praktis). Jakarta: Lembaga Penerbit FE UI, Cetakan 1.

Alfitri. (2011). Community Development (Teori dan Aplikasi). Yogyakarta: Pustaka Pelajar, Cetakan 1.

Arikunto, Suharsimi. (2015). Prosedur Penelitian Suatu Pendekatan Praktek. Jakarta: Rineka Cipta.

Elly. (2006). Ilmu Sosial Budaya Dasar. Jakarta: Prenamedia Group.

Hartati. (2006). Ibu Teladan di Era Global: Dalam Perspektif Islam. Jakarta: Pusat Studi Wanita (PSW) UIN Syarif Hidayatullah Jakarta. 
Kepmendagri No. 132/2003.

Narbuko, Cholid. (2007). Metodologi Penelitian. Jakarta: Bumi Aksara.

Noerdin. Edriana. (2006). Potret Kemiskinan Perempuan. Jakarta: Women Research Institute. Cetakan Kesatu.

Pusat Pembinaan dan Pengembangan Bahasa Depdikbud. (1990). Kamus Besar Bahasa Indonesia. Jakarta: Balai Pustaka.

Sadono, Sukirno. (2006). Makroekonomi Teori Pengantar Edisi Ketiga. Jakarta: Raja Grafindo Persada.

Soemitro, Ronny Hanitijo. (1985). Metodologi Penelitian Hukum. Jakarta: Ghalia Indonesia, Cetakan II.

Shihab, Quraish. (2006). Perempuan. Jakarta: Lentera Hati.

Subagyo, Joko. (2004). Metode Penelitian Dalam Teori dan Praktek. Jakarta: Rineka Cipta, Cetakan Ke 4.

Suharto, Edi. (2009). Membangun Masyarakat Memberdayakan Rakyat Kajian Strategis Pembangunan Kesejahteraan Sosial dan Pekerjaan Sosial. Bandung: PT. Refika Aditama. Cetakan Ketiga.

Sumardiono. (2007). Homeschooling : A Leap For Better Learning. Jakarta: PT Elex Media Komputindo.

Tim Penyusun. (1992). Buku III: Pengantar Teknik Analisis Jender, Jakarta: Kantor Menteri Negara Urusan Peranan Wanita.

Usman, Husaini. (1996). Metodologi Penelitian Sosial. Jakarta: Bumi Aksara, Cetakan I. 